\title{
MATRIK
}

Jurnal Manajemen dan Teknik Industri-Produksi

Journal homepage: http://www.journal.umg.ac.id/index.php/matriks

\section{Pemilihan Metode Peramalan Jumlah Permintaan Koran dengan Tingkat Kesalahan Terendah}

\author{
Azizah Hadny Qurrota A'yun', Hanif Ardian², Maulidina Khairannisa Nunuh ${ }^{3}$, Sherlinta \\ Immanuella $^{4}$,Yuniaristanto ${ }^{5}$, Wahyudi Sutopo ${ }^{6 *}$
}

Program Studi Teknik Industri, Fakultas Teknik, Universitas Sebelas Maret

Jl. Ir. Sutami 36 A, Surakarta, 57126, Jawa Tengah, Indonesia

wahyudisutopo@staff.uns.ac.id

\begin{tabular}{l} 
INFO ARTIKEL \\
\hline Jejak Artikel : \\
Upload artikel \\
O8 Maret 2020 \\
Revisi dari reviewer \\
1O Maret 2020 \\
Publish \\
30 Maret 2021 \\
\hline
\end{tabular}

Kata Kunci :

moving average, exponential smoothing, trend line analysis, peramalan,koran, $M A P E$
ABSTRAK

Pada era digital saat ini, banyak sekali industri yang mengalami dampak dari digitalisasi, salah satunya adalah industri surat kabar (koran). Adanya digitalisasi menyebabkan permintaan koran semakin fluktuatif dan sulit diprediksi. Hal ini juga menyebabkan tingkat retur atau pengembalian koran dari agen-agen yang cukup tinggi dan tentu saja akan memberikan kerugian yang cukup besar bagi perusahaan. Untuk itu, perlu dilakukan penentuan métode peramalan jumlah permintaan koran yang memiliki tingkat kesalahan terkecil sehingga dapat membantu perusahaan mengurangi kerugian akibat retur koran. Penelitian ini menghitung peramalan permintaan menggunakan beberapa metode antara lain trend line analysis, double exponential smoothing, dan two months moving average. Selain itu, penelitian ini juga membandingkan hasil peramalannya dengan penelitian terdahulu yang menggunakan metode ARIMA. Pemilihan metode peramalan yang terbaik dilakukan dengan membandingkan tingkat kesalahan (MAPE) dari tiap-tiap metode kemudian dipilih metode dengan tingkat kesalahan terkecil. Berdasarkan perbandingan yang dilakukan, dapat diketahui bahwa metode peramalan yang memiliki tingkat kesalahan terkecil adalah metode trend line analysis dengan nilai MAPE sebesar 2,94\%. Oleh karena itu, metode peramalan yang terbaik untuk melakukan peramalan permintaan jumlah koran di Kota Surakarta adalah metode trend line analysis. 


\section{Pendahuluan}

Pada era serba digital seperti saat ini, sangat banyak industri yang terkena dampak dari kejamnya digitalisasi, salah satunya adalah industri surat kabar (koran). Permintaan yang fluktuatif yang cenderung menurun menjadi tantangan tersendiri bagi pelaku bisnis, termasuk pada PT. Aksara Solopos. Perusahaan koran ini memesan sejumlah koran setiap harinya kepada sebuah perusahaan percetakan yang bertugas sebagai pencetak. Sebagai distributor tunggal, perusahaan koran ini memiliki beberapa agen di wilayah eksKaresidenan Surakarta. Dalam penjualan koran, seringkali terjadi lonjakan pada momen tertentu, seperti adanya event Solo Batik Carnival, banjir, puting beliung, dan sebagainya. Hal ini harus diantisipasi dengan meminimalisir jumlah koran yang kurang. Akibat terjadinya digitalisasi, perusahaan koran ini juga harus mengantisipasi adanya koran retur. Koran yang retur ini tentu merugikan pihak perusahaan koran ini. Tercatat rata-rata koran retur dari agen ke Perusahaan koran ini yaitu sebesar 5\%. Jika diambil kasus pada tahun 2017, laporan penjualan total pada perusahaan koran ini adalah sekitar Rp 18.400.000.000 [1].

Jika harus menanggung retur koran yang sebesar 5\% saja nilai kerugiannya sudah mencapai Rp 920.000.000. Kerugian akibat retur ini disebabkan karena koran memiliki karakter unik, yaitu produksi harian dan tidak ada stok karena memberitakan informasi terbaru [1]. Jika informasi terlambat maka koran tidak dapat dijual. Tujuan dari penelitian ini adalah untuk menentukan metode yang tepat dalam peramalan jumlah produksi koran dengan tingkat kesalahan seminimal mungkin. Untuk meramalkan permintaan, maka akan dilakukan peramalan dengan membandingkan tiga metode yaitu metode trend line analysis, double exponential smoothing, dan two months moving average. Selain itu, akan dilakukan perbandingan pula dengan metode ARIMA yang digunakan pada penelitian terdahulu [2].

Ada beberapa masalah dalam penyelesaian supply chain mengenai koran. Ada ketidaktepatan penawaran dengan permintaan yang berarti bahwa banyak surat kabar dikembalikan [2]. Dengan permasalahn tersebut maka Model ARIMA dipilih karena memberikan nilai terkecil dari kesalahan persentase absolut rata-rata (MAPE) [2]. Selain itu, produksi surat kabar dituntut memiliki tingkat efisiensi yang tinggi karena siklus waktu produksinya sangat terbatas [3]. Metode Discrete Event Simulation (DES) adalah dipilih sebagai solusi dalam pemodelan sistem sebenarnya yang dapat menggambarkan berbagai komponen dalam proses produksi koran, hal ini digunakan agar bisa mendapatkan skenario terbaik dalam proses produksi koran [3]. Industri koran juga melakukan penelitian mengenai pengiriman bersama untuk memamngkas biaya yang dikeluarkan oleh perusahaan, hal ini dilakukan dengan perhitungan biaya distribusi menggunakan pendekatan Vehicle Routing Problem with Time Windows (VRPTW) hingga dapat menghemat hingga $72.22 \%$ [4]. Pendekatan Problem Based Learning (PBL) dapat digunakan untuk pembelajaran dan industri surat kabar untuk menangkap masalah sistem nyata [5].

Metode peramalan merupakan metode yang digunakan untuk mengestimasikan obyek yang diteliti, dalam hal ini adalah peramalan tingkat penjualan koran. Peramalan (forecasting) adalah suatu seni dan ilmu pengetahuan dalam memprediksi peristiwa pada masa yang akan datang. Peramalan adalah suatu kegiatan yang memperkirakan sesuatu hal yang akan terjadi di masa yang akan datang. Peramalan akan melibatkan mengambil data historis (seperti penjualan tahun lalu) dan memproyeksikan mereka ke masa yang akan datang dengan menggunakan model matematika [6]. Pengumpulan data yang relevan berupa informasi dapat menghasilkan peramalan yang akurat disertai pemilihan teknik peramalan yang tepat maka pemanfaatan informasi data akan diperoleh secara optimal. Peramalan tidak memberikan jawaban yang pasti tentang apa yang akan terjadi, tetapi berusaha mencari sedekat mungkin dengan yang akan terjadi [7]. Dari data yang dihimpun, 
penulis mengusulkan penerapan tiga metode yaitu metode trend line analysis, double exponential smoothing, dan two months moving average. Dari penerapan ketiga metode tersebut, kemudian akan dibuat perbandingan efektifitas metode yang di ukur melalui akurasi data aktual dan hasil peramalan dengan cara mengetahui tingkat kesalahan peramalan. Metode perhitungan kesalahan peramalan yang digunakan adalah Mean Absolute Percentage Error (MAPE). Hasil pengolahan data peramalan diharapkan menghasilkan peramalan dengan nilai kesalahan yang paling kecil, sehingga pihak perusahaan koran dapat mengestimasikan jumlah koran yang akan di produksi perusahaan percetakan, sehingga tidak terjadi kekurangan atau retur koran oleh agen.

Penelitian ini mengacu pada penelitian yang telah dilakukan oleh Permatasari et al terhadap peramalan penjualan koran pada perusahaan koran yang sama. Berdasarkan hasil penelitian, ditemukan masalah yang terjadi adalah besarnya retur yang dilakukan oleh agen distribusi. Sehingga perlu dilakukan peramalan dengan memperkecil bias yang mungkin terjadi. Pada penelitian terdahulu, metode yang digunakan dalam peramalan adalah metode ARIMA.

\section{Tinjauan Pustaka}

Peramalan merupakan alat bantu yang penting dalam perencanaan yang efektif dan efisien. Terdapat berbagai metode yang dapat digunakan dalam melakukan peramalan permintaan. Berikut ini merupakan metode peramalan yang digunakan dalam penelitian ini:

\section{a. Metode Trend Line Analysis}

Metode peramalan ini memiliki syarat bahwa pegerakan data tersebut adanya pola yang terus meningkat atau terus menurun dengan pola yang relatif berulang [8].

$$
\begin{aligned}
& \mathrm{Ft}=\mathrm{a}+\mathrm{bt} \\
& \mathrm{a}=\overline{\mathrm{A}}-\mathrm{b} \overline{\mathrm{t}} \\
& \mathrm{b}=\frac{\sum \mathrm{tA}-\mathrm{n} \overline{\mathrm{t}}}{\sum \mathrm{t}^{2}-\mathrm{n} \overline{\mathrm{t}}^{2}}
\end{aligned}
$$

Keterangan

Ft : Nilai peramalan

$\mathrm{a}:$ Intersept

$\mathrm{A}^{-}$: Nilai rata - rata permintaan per periode

$A$ : Data aktual permintaan

b : slope

$\mathrm{t}:$ Indeks waktu

\section{b. Metode Double Exponential Smoothing}

Dalam meramalkan data, Exponential Smoothing akan menaksirkan berapa nilai rataan data yang ada kemudian digunakan untuk mendapatkan nilai peramalan pada periode selanjutnya [9]. Double Exponential Smoothing merupakan model yang di kemukakan oleh Holt, model ini sering digunakan pada data yang tidak dipengaruhi tren atau musim karena data cenderung linier [10]. Untuk meramalkan permintaan di periode berikutnya, harus diketahui ramalan level atau nilai penghalusan baru dan estimasi trend nya [11]. Keunggulan metode exponential smoothing adalah dapat memberikan ketepatan dalam ramalan jangka pendek dan penyesuaian dapat dilakukan dengan cepat dan pada biaya yang rendah [12].

Nilai smoothing ke-t :

$\mathrm{F}_{\mathrm{t}}=\alpha \times \mathrm{A}_{\mathrm{t}-1}+(1-\alpha) \times\left(\mathrm{F}_{\mathrm{t}-1}+\mathrm{T}_{\mathrm{t}-1}\right)$

Estimasi trend ke-t :

$\mathrm{Tt}=\beta \times\left(\mathrm{F}_{\mathrm{t}}-\mathrm{F}_{\mathrm{t}-1}\right)+(1-\beta) \times \mathrm{T}_{\mathrm{t}-1}$

Hasil peramalan ke-t :

$\mathrm{Dt}=\mathrm{Ft}+\mathrm{Tt}$

Keterangan

$\mathrm{Ft}=$ Peramalan untuk periode $\mathrm{t}$.

At $+1+(1-\alpha)=$ Nilai aktual time series

$\mathrm{Tt}=$ trend pada periode $\mathrm{ke}-\mathrm{t}$

$\alpha=$ parameter pertama perataan antara nol dan

$1,=$ untuk smoothing nilai observasi 
$\beta=$ parameter kedua, untuk pemulusan trend

$\mathrm{Dt}=$ Hasil akhir peramalan periode $\mathrm{ke}-\mathrm{t}$

\section{c. Metode Two Months Moving Average}

Tujuan utama dari penggunaaan moving average adalah untuk mengurangi randomness dalam deret waktu. Teknik ini terdiri dari menggunakan nilai dengan n-bulan, mengambil rataan dari nilai ini, kemudian menggunakan nilai rataan tersebut sebagai ramalan untuk periode yang akan datang [13].

$\mathrm{Dt}=\frac{\mathrm{D}_{\mathrm{t}-1}+\mathrm{D}_{\mathrm{t}-2}}{2}$

Keterangan

$\mathrm{Dt}=$ Hasil peramalan periode $\mathrm{ke}-\mathrm{t}$

Dt-1 = Hasil peramalan periode ke $-\mathrm{t}-1$

Dt-2 $=$ Hasil peramalan periode ke $-\mathrm{t}-2$

d. Mean Absolute Persentage Error (MAPE)

MAPE digunakan untuk mencari persentase rataan bias absolut [14]. MAPE dihitung sebagai rataan diferensiasi absolut antara nilai yang diramalkan dan aktual, dinyatakan sebagai persentase nilai actual [15].

MAPE $=\left(\frac{100}{n}\right) \Sigma\left|A_{t}-\frac{F_{t}}{A_{t}}\right|(8)$

Keterangan

At $=$ Permintaan aktual pada periode $-\mathrm{t}$

$\mathrm{Ft}=$ Peramalan permintaan (forecast) pada periode-t

$\mathrm{n}=$ Jumlah periode peramalan yang terlibat

\section{e. Tracking Signal}

Tracking Signal digunakan untuk validasi model [16]. Tracking signal yang positif menunjukkan bahwa nilai aktual permintaan lebih besar daripada ramalan, sedangkan apabila negatif berarti nilai aktual permintaan lebih kecil daripada ramalan. Tracking signal yang baik memiliki kesalahan positif yang sama dengan kesalahan negatif, sehingga tracking signal mendekati nol [17]. Jika peta kontrol tracking signal tidak melebihi batas atas dan batas bawah yaitu +4 dan -4 maka dapat dilakukan peramalan jumlah permintaan produk [18].

$$
\begin{aligned}
\text { Tracking Signal } & =\frac{\text { RSFE }}{\mathrm{MAD}} \\
& =\frac{\Sigma(\text { actual }- \text { forecast })}{\mathrm{MAD}}
\end{aligned}
$$

$\mathrm{MAD}=\frac{\Sigma(\mathrm{Yi}-\overline{\mathrm{Y}} \mathrm{i})}{\mathrm{n}}$

Keterangan

Yi $=$ Data pada periode ke-i

$\mathrm{n}=$ Jumlah periode peramalan yang terlibat

\section{Metode Penelitian}

Metode yang digunakan penulis dalam penelitian ini terdapat tiga metode yaitu Trend Line Analysis, Double Exponential Smoothing, dan Two Months Moving Average. Ketiga metode diimplementasikan dan kemudian dibandingkan untuk mendapatkan hasil metode mana yang paling akurat dalam meramalkan penjualan untuk periode yang akan datang, akurasi hasil ini di peroleh dari perhitungan tingkat kesalahan dengan menggunakan Mean Absolute Percentage Error (MAPE) dan Tracking Signal. Agar diperoleh data yang paling akurat untuk peramalan yang akan datang.

Data yang digunakan sebagai studi kasus peramalan jumlah permintaan adalah data penjualan periode Januari 2016 hingga Maret 2017. Data diperoleh melalui penelitian terdahulu dan melalui wawancara dengan staff.

\section{Hasil dan Pembahasan}

Data yang digunakan adalah data penjualan koran selama bulan Januari 2016 sampai bulan Maret 2017. Berikut ini merupakan pola data penjualan dari bulan Januari 2016-Maret 2017. 


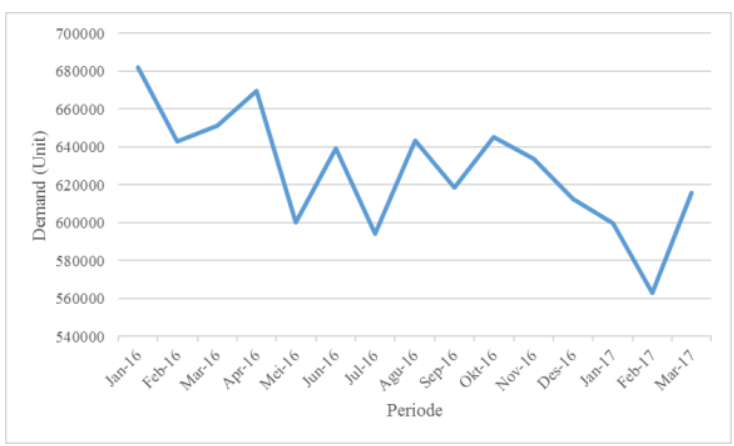

Gambar 1. Grafik Data Permintaan Koran

Data permintaan tersebut kemudian diolah menggunakan beberapa metode antara lain trend line analysis, double exponential smoothing, dan two months moving average. Hasil peramalan permintaan dengan beberapa metode tersebut akan dibandingkan pula dengan hasil penelitian terdahulu yaitu Modelling and Sales Forecasting Newspaper with ARIMA [2] dengan studi kasus di perusahaan yang sama.

\section{a. Peramalan Dengan Metode Trend Line Analysis}

Peramalan dengan trend line analysis dilakukan dengan memodelkan data historis yang ada menjadi sebuah persamaan linier. Persamaan linier ditentukan dengan menghitung nilai a dan $\mathrm{b}$ menggunakan persamaan (2) dan (3). Persamaan linier dapat dibentuk menggunakan persamaan (1). Kemudian, peramalan pada periode selanjutnya dapat dihitung dengan persamaan linier tersebut. Berikut ini merupakan perhitungan dalam memperoleh persamaan regresi linier yang digunakan dalam peramalan.

Diketahui :

$$
\begin{aligned}
& \sum \mathrm{t} A=73999062 \quad \bar{A}=627452 \\
& \mathrm{n}=15 \\
& \quad \sum \mathrm{t}^{2}=1240 \\
& \overline{\mathrm{t}}=8 \\
& \text { Perhitungan : } \\
& \mathrm{b}=\frac{\sum \mathrm{tA}-\mathrm{n} \overline{\mathrm{t}} \mathrm{A}}{\sum \mathrm{t}^{2}-\mathrm{n} \overline{\mathrm{t}}^{2}} \\
& \mathrm{~b}=\frac{73999062-15 \times 8 \times 627452}{1240-15 \times 8^{2}} \\
& \mathrm{~b}=-4625,721 \\
& \mathrm{a}=\overline{\mathrm{A}}-\mathrm{b} \overline{\mathrm{t}} \\
& \mathrm{a}=627452-(-4625,721) \times 8
\end{aligned}
$$

$\mathrm{a}=664457,971$

Berdasarkan perhitungan tersebut diperoleh persamaan

$$
\begin{aligned}
& \mathrm{Ft}=664457,971-4625,721 \mathrm{t} \\
& \text { Dimana : }
\end{aligned}
$$

$$
\mathrm{Ft}=\text { hasil peramalan periode } \mathrm{t}
$$

Berikut ini merupakan data aktual, hasil peramalan, tracking signal, dan MAPE menggunakan metode trend line analysis.

Tabel 1. Hasil Peramalan dan Tingkat Kesalahan Metode Trend Line Analysis

\begin{tabular}{ccccc}
\hline Period (t) & $\begin{array}{c}\text { Actual } \\
\text { Demand } \\
(\text { A })\end{array}$ & $\begin{array}{c}\text { Demand } \\
\text { Forecast } \\
\text { (D) }\end{array}$ & $\begin{array}{c}\text { Tracking } \\
\text { Signal }\end{array}$ & $\begin{array}{c}\text { Absolute } \\
\text { Percent } \\
\text { Error (\%) }\end{array}$ \\
\hline Jan-16 & 682177 & 659832 & 1.00 & 3.28 \\
Feb-16 & 643154 & 655207 & 0.60 & 1.87 \\
Mar-16 & 651105 & 650581 & 0.93 & 0.08 \\
Apr-16 & 669641 & 645955 & 2.35 & 3.54 \\
May-16 & 600311 & 641329 & -0.33 & 6.83 \\
Jun-16 & 639149 & 636704 & -0.24 & 0.38 \\
Jul-16 & 594268 & 632078 & -2.10 & 6.36 \\
Aug-16 & 643260 & 627452 & -1.34 & 2.46 \\
Sep-16 & 618726 & 622826 & -1.70 & 0.66 \\
Oct-16 & 645388 & 618201 & -0.16 & 4.21 \\
Nov-16 & 633852 & 613575 & 0.92 & 3.20 \\
Dec-16 & 612400 & 608949 & 1.18 & 0.56 \\
Jan-17 & 599836 & 604324 & 0.98 & 0.75 \\
Feb-17 & 562901 & 599698 & -1.14 & 6.54 \\
Mar-17 & 615615 & 595072 & 0.00 & 3.34 \\
Apr-17 & & 590446 & & \\
\hline \multicolumn{5}{c}{ MAPE } \\
\hline
\end{tabular}

Hasil peramalan menggunakan metode trend line analysis menunjukkan permintaan pada bulan April 2017 sebanyak 590446 koran. Hasil peramalan dengan metode ini memiliki tingkat kesalahan (MAPE) sebesar 2,94\%. Nilai tracking signal menunjukkan tingkat kebiasan data, dimana apabila nilai tracking signal berada di antara -4 dan 4 maka data tidak bias. Namun jika sebaliknya, maka data dikatakan bias. Pada peramalan dengan metode 
trend line analysis, nilai tracking signal terakhir berada di antara -4 dan 4 sehingga hasil peramalan ini dikatakan tidak bias.

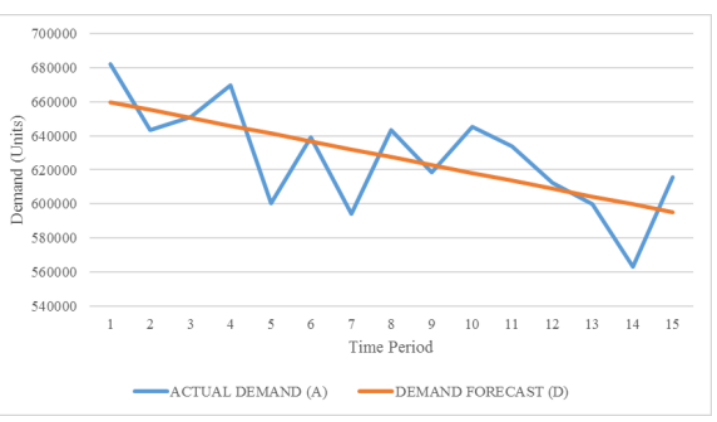

Gambar 2. Grafik Perbandingan Aktual dan Peramalan Metode Trend Line Analysis

Berdasarkan grafik tersebut, dapat diketahui bahwa persebaran data aktual tidak jauh dari kurva hasil peramalan kecuali pada data ke 14. Hal ini menunjukkan bahwa tingkat kesalahan peramalan dengan metode trend line analysis cukup kecil, karena data tidak tersebar jauh dari kurva.

\section{b. Peramalan Dengan Metode Double Exponential Smoothing}

Peramalan dengan double exponential smoothing dilakukan dengan menggunakan dua parameter yaitu $\alpha$ dan $\beta$. Nilai $\alpha$ dan $\beta$ diperoleh menggunakan solver pada perangkat lunak Microsoft Excel hingga mendapatkan nilai $\alpha$ dan $\beta$ yang memiliki tingkat kesalahan terendah dan nilai tracking signal antara -4 dan 4 . Setelah dilakukan perhitungan menggunakan excel solver, diperoleh nilai $\alpha$ sebesar 0,15277 dan $\beta$ sebesar 0,99983 . Parameter $\alpha$ digunakan pada smoothing dengan persamaan (4) dan $\beta$ digunakan untuk mengestimasi trend pada persamaan (5). Setelah itu, nilai peramalan dapat dihitung menggunakan persamaan (6). Berikut ini merupakan contoh perhitungan peramalan dengan metode double exponential smoothing.

Contoh perhitungan nilai smoothing ke -2

$$
\mathrm{Ft}=\alpha \mathrm{A}_{\mathrm{t}-1}+(1-\alpha)\left(\mathrm{F}_{\mathrm{t}-1}+\mathrm{T}_{\mathrm{t}-1}\right)
$$

$\mathrm{Ft}=0,15277 \times 682177+(1-0,15277)(627452+0)$

$\mathrm{Ft}=635812$

Contoh perhitungan estimasi trend ke-2

$\mathrm{Tt}=\beta\left(\mathrm{F}_{\mathrm{t}}-\mathrm{F}_{\mathrm{t}-1}\right)+(1-\beta) \mathrm{T}_{\mathrm{t}-1}$

$$
\begin{aligned}
& \mathrm{Tt}=0,99983(635812-627452)+(1-0,99983) \times 0 \\
& \mathrm{Tt}=8358,85 \\
& \text { Contoh perhitungan hasil peramalan ke- } 2 \\
& \mathrm{Dt}=\mathrm{Ft}+\mathrm{Tt} \\
& \mathrm{Dt}=635812+8358,85 \\
& \mathrm{Dt} \approx 644171
\end{aligned}
$$

Berikut ini merupakan data aktual, hasil peramalan, tracking signal, dan MAPE menggunakan metode double exponential smoothing.

Tabel 2. Hasil Peramalan dan Tingkat Kesalahan Metode Double Exponential Smoothing

\begin{tabular}{ccccc}
\hline $\begin{array}{c}\text { Period } \\
(\mathrm{t})\end{array}$ & $\begin{array}{c}\text { Actual } \\
\text { Demand } \\
(\mathrm{A})\end{array}$ & $\begin{array}{c}\text { Demand } \\
\text { Forecast } \\
(\mathrm{D})\end{array}$ & $\begin{array}{c}\text { Tracking } \\
\text { Signal }\end{array}$ & $\begin{array}{c}\text { Absolute } \\
\text { Percent } \\
\text { Error } \\
(\%)\end{array}$ \\
\hline 16-Jan & 682177 & & & \\
16-Feb & 643154 & 644171 & -1 & 0.16 \\
16-Mar & 651105 & 652219 & -2 & 0.17 \\
16-Apr & 669641 & 660082 & 1.91 & 1.43 \\
16-May & 600311 & 671036 & -3.07 & 11.78 \\
16-Jun & 639149 & 658922 & -4.06 & 3.09 \\
16-Jul & 594268 & 651572 & -5.28 & 9.64 \\
16-Aug & 643260 & 629735 & -5.13 & 2.1 \\
16-Sep & 618726 & 620785 & -5.89 & 0.33 \\
16-Oct & 645388 & 609139 & -3.95 & 5.62 \\
16-Nov & 633852 & 608883 & -2.86 & 3.94 \\
16-Dec & 612400 & 610717 & -3.05 & 0.27 \\
17-Jan & 599836 & 609251 & -3.66 & 1.57 \\
17-Feb & 562901 & 604651 & -5.27 & 7.42 \\
17-Mar & 615615 & 588735 & -4 & 4.37 \\
17-Apr & & 587409 & & \\
\hline \multicolumn{5}{c}{ MAPE } \\
\hline
\end{tabular}

Hasil peramalan menggunakan metode double exponential smoothing menunjukkan permintaan pada bulan April 2017 sebanyak 587409 koran. Hasil peramalan dengan metode ini memiliki tingkat kesalahan (MAPE) sebesar $3,71 \%$. Nilai tracking signal menunjukkan tingkat kebiasan data, dimana apabila nilai tracking signal berada di antara -4 dan 4 maka data tidak bias. Namun jika sebaliknya, maka data dikatakan bias. Pada peramalan dengan metode trend line analysis, nilai tracking signal 
terakhir berada di antara -4 dan 4 sehingga hasil peramalan ini dikatakan tidak bias.

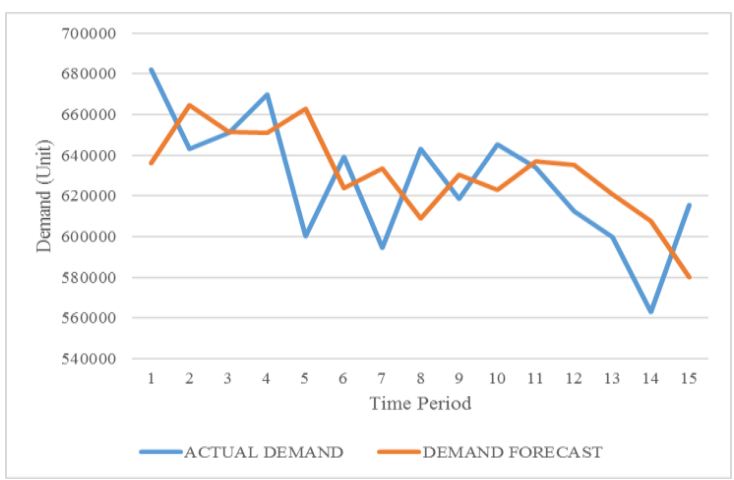

Gambar 3. Grafik Perbandingan Aktual dan Peramalan Metode Double Exponential Smoothing

Berdasarkan grafik tersebut, dapat diketahui bahwa terjadi perbedaan yang cukup jauh antara hasil peramalan dengan metode double exponential smoothing dan data aktual pada periode ke 5, 6,7,10, dan 11. Pada periode ke 5, 6, dan 7, hasil peramalan permintaan cukup jauh lebih tinggi dari pada nilai aktualnya. Sedangkan pada periode ke 10 dan 11, hasil peramalan permintaan lebih rendah daripada nilai aktualnya.

\section{c. Peramalan Dengan Metode Two Months Moving Average}

Peramalan dengan metode two months moving average dilakukan dengan menghitung nilai rata-rata dari dua periode sebelum periode yang akan diramalkan menggunakan persamaan (7).

Contoh perhitungan peramalan periode ke-3

$$
\begin{aligned}
& \mathrm{Dt}=\frac{\mathrm{D}_{\mathrm{t}-1}+\mathrm{D}_{\mathrm{t}-2}}{2} \\
& \mathrm{Dt}=\frac{682177+643154}{2} \\
& \mathrm{Dt}=662666
\end{aligned}
$$

Berikut ini merupakan data aktual, hasil peramalan, tracking signal, dan MAPE menggunakan metode two months moving average.
Tabel 3. Hasil Peramalan dan Tingkat Kesalahan Metode Double Exponential Smoothing

\begin{tabular}{ccccc}
\hline $\begin{array}{c}\text { Period } \\
(\mathrm{t})\end{array}$ & $\begin{array}{c}\text { Actual } \\
\text { Demand } \\
(\mathrm{A})\end{array}$ & $\begin{array}{c}\text { Demand } \\
\text { Forecast } \\
(\mathrm{D})\end{array}$ & $\begin{array}{c}\text { Tracking } \\
\text { Signal }\end{array}$ & $\begin{array}{c}\text { Absolute } \\
\text { Percent } \\
\text { Error } \\
(\%)\end{array}$ \\
\hline 16-Jan & 682177 & & & \\
16-Feb & 643154 & & & \\
16-Mar & 651105 & 662666 & -1 & 1.78 \\
16-Apr & 669641 & 647130 & 0.64 & 3.36 \\
16-May & 600311 & 660373 & -1.57 & 10.01 \\
16-Jun & 639149 & 634976 & -1.83 & 0.65 \\
16-Jul & 594268 & 619730 & -2.84 & 4.28 \\
16-Aug & 643260 & 616709 & -1.75 & 4.13 \\
16-Sep & 618726 & 618764 & -2.04 & 0.01 \\
16-Oct & 645388 & 630993 & -1.43 & 2.23 \\
16-Nov & 633852 & 632057 & -1.5 & 0.28 \\
16-Dec & 612400 & 639620 & -2.83 & 4.44 \\
17-Jan & 599836 & 623126 & -3.96 & 3.88 \\
17-Feb & 562901 & 606118 & -5.6 & 7.68 \\
17-Mar & 615615 & 581369 & -3.85 & 5.56 \\
17-Apr & & 589258 & & \\
\hline \multicolumn{5}{c}{ MAPE } \\
\hline
\end{tabular}

Hasil peramalan menggunakan metode $t w o$ months moving average menunjukkan permintaan pada bulan April 2017 sebanyak 589258 koran. Hasil peramalan dengan metode ini memiliki tingkat kesalahan (MAPE) sebesar $3,72 \%$. Nilai tracking signal menunjukkan tingkat kebiasan data, dimana apabila nilai tracking signal berada di antara -4 dan 4 maka data tidak bias. Namun jika sebaliknya, maka data dikatakan bias. Pada peramalan dengan metode trend line analysis, nilai tracking signal terakhir berada di antara -4 dan 4 sehingga hasil peramalan ini dikatakan tidak bias.

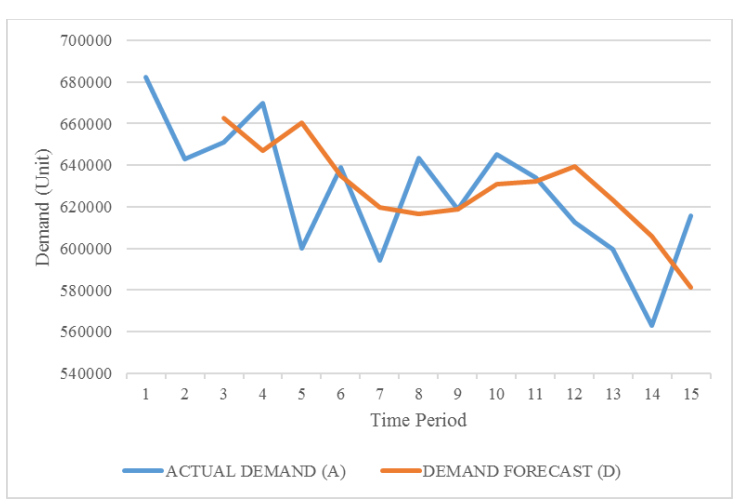

Gambar 4. Grafik Perbandingan Aktual dan Peramalan Metode Two Months Moving Average 
Berdasarkan grafik tersebut, dapat diketahui bahwa terjadi perbedaan yang cukup jauh antara hasil peramalan dengan metode two months moving average dan data aktual pada periode ke 5 dan 14.

\section{d. Perbandingan Hasil Peramalan Jumlah Permintaan Koran}

Hasil peramalan jumlah permintaan koran dapat dibandingkan berdasarkan perhitungan yang dilakukan dengan metode trend line analysis, double exponential smoothing, dan two months moving average. Selain itu, penelitian tersahulu telah melakukan peramalan jumlah permintaan koran dengan menggunakan metode ARIMA pada studi kasus yang sama [2]. Oleh karena itu, hasil peramalan permintaan juga akan dibandingkan dengan penelitian terdahulu yang menggunakan metode ARIMA sehingga dapat diperoleh metode peramalan jumlah permintaan koran terbaik.

Berikut ini merupakan tabel perbandingan hasil peramalan, tingkat kesalahan (MAPE), dan tracking signal dengan metode trend line analysis, double exponential smoothing, two months moving average, dan ARIMA.

Tabel 4. Perbandingan Hasil Peramalan dengan Berbagai Metode

\begin{tabular}{|c|c|c|c|c|}
\hline $\begin{array}{l}\text { Metode } \\
\text { Peramalan }\end{array}$ & $\begin{array}{c}\text { Hasil } \\
\text { Peramalan } \\
\text { April } \\
2017 \\
\text { (unit) } \\
\end{array}$ & $\begin{array}{c}\text { MAPE } \\
(\%)\end{array}$ & $\begin{array}{c}\text { Tracking } \\
\text { Signal }\end{array}$ & Keterangan \\
\hline $\begin{array}{l}\text { Trend Line } \\
\text { Analysis }\end{array}$ & 590446 & 2.94 & 0 & $\begin{array}{c}\text { TIDAK } \\
\text { BIAS }\end{array}$ \\
\hline $\begin{array}{l}\text { Double } \\
\text { Exponential } \\
\text { Smoothing }\end{array}$ & 587409 & 3.71 & -4 & $\begin{array}{c}\text { TIDAK } \\
\text { BIAS }\end{array}$ \\
\hline $\begin{array}{l}\text { Moving } \\
\text { Average }\end{array}$ & 589258 & 3.72 & -3.848 & $\begin{array}{l}\text { TIDAK } \\
\text { BIAS }\end{array}$ \\
\hline ARIMA & 628300 & 3,52 & & \\
\hline $\begin{array}{c}\text { METODE } \\
\text { TERPILIH }\end{array}$ & 2.94 & $\begin{array}{r}\text { Tren } \\
\text { Anc }\end{array}$ & $\begin{array}{l}\text { d Line } \\
\text { alysis }\end{array}$ & \\
\hline
\end{tabular}

Hasil perhitungan peramalan jumlah permintaan koran menggunakan metode trend line analysis menunjukkan permintaan pada bulan April 2017 sebanyak 590446 eksemplar dengan tingkat kesalahan (MAPE) sebesar
2,94\%. Perhitungan peramalan jumlah permintaan koran menggunakan metode double exponential smoothing menunjukkan permintaan pada bulan April 2017 sebanyak 587409 eksemplar dengan tingkat kesalahan (MAPE) sebesar 3,71\%. Perhitungan peramalan jumlah permintaan koran menggunakan metode two months moving average menunjukkan permintaan pada bulan April 2017 sebanyak 589258 eksemplar dengan tingkat kesalahan (MAPE) sebesar 3,72\%. Berdasarkan penelitian terdahulu yang telah dilakukan [2] pada studi kasus yang sama, perhitungan peramalan jumlah permintaan koran menggunakan metode ARIMA menunjukkan permintaan pada bulan April 2017 sebanyak 628300 eksemplar dengan tingkat kesalahan (MAPE) sebesar 3,52\%.

Berdasarkan hasil perbandingan tersebut, dapat diketahui bahwa metode peramalan dengan tingkat kesalahan (MAPE) terkecil adalah metode trend line anlaysis yang memiliki tingkat kesalahan sebesar $2.94 \%$. Oleh karena itu, metode peramalan yang sesuai digunakan dalam peramalan jumlah permintaan koran di Surakarta adalah metode trend line analysis karena memiliki tingkat kesalahan paling kecil dibanding metode lainnya. Pemilihan metode peramalan yang tepat dapat mengurangi tingkat pengembalian atau retur koran ke perusahaan dan dapat mengurangi kerugian perusahaan.

\section{Kesimpulan dan Saran}

Penelitian ini akan menggambarkan kondisi peramalan permintaan koran dengan menggunakan berbagai metode. Metode ini dibandingkan untuk mendapatkan metode yang sesuai dengan permasalahan yang ada.

Dari analisis yang telah dilakukan dengan beberapa metode, metode double exponential smoothing tingkat kesalahan $3.71 \%$, metode moving average tingkat kesalahan $3.72 \%$, metode ARIMA tingkat kesalahan 3.52\%, dan trend line analysis dengan tingkat kesalahan sebesar 2,94\%. Dapat diketahui bahwa metode yang paling sesuai digunakan untuk melakukan peramalan jumlah permintaan koran di 
Surakarta adalah metode trend line analysis dengan tingkat kesalahan sebesar 2,94\%.

Hasil penelitian ini dapat digunakan perusahaan untuk melakukan perencanaan produksi sehingga nantinya tingkat pengembalian atau retur koran dapat menjadi lebih rendah, dan perusahaan dapat menekan kerugian yang terjadi.

Pengembangan dari penelitian ini dapat dilakukan dengan membandingkan metode trend line analysis dengan metode lain yang lebih terdepan seperti metode jaringan syaraf tiruan backpropagation dengan melakukan pengumpulan data yang lebih banyak terlebih dahulu.

\section{Daftar Pustaka}

[1] A. N. Wijiyanto, D. E. Kusrinid, and I. Irhamah, "Peramalan Nilai Kontrak Konstruksi PT 'X'dengan Menggunakan Pendekatan Regresi Time Series dan ANFIS," J. Sains dan Seni ITS, vol. 1, no. 1, pp. D201D206, 2012.

[2] C. I. Permatasari, W. Sutopo, and M. Hisjam, "Sales forecasting newspaper with ARIMA: A case study," in AIP Conference Proceedings, 2018, vol. 1931, doi: 10.1063/1.5024076.

[3] O. Riskadayanti, Yuniaristanto, W. Sutopo, and M. Hisjam, "Discreteevent simulation of a production process for increasing the efficiency of a newspaper production," IOP Conf. Ser. Mater. Sci. Eng., vol. 495, no. 1, 2019, doi: 10.1088/1757899X/495/1/012026.

[4] M. N. A. Jodinesa, Yuniaristanto, W. Sutopo, and M. Hisjam, "Joint delivery planning with time windows: A case study on supply chain in newspaper industry," IOP Conf. Ser. Mater. Sci. Eng., vol. 495, no. 1, 2019, doi: 10.1088/1757899X/495/1/012034.
[5] W. Sutopo and E. F. Aqidawati, "Learning a Supply Chain Management course by Problem Based Learning: Case studies in the newspaper industry," Proc. Int. Conf. Ind. Eng. Oper. Manag., vol. 2019, no. MAR, pp. 3559-3570, 2019.

[6] H. Jay and R. Barry, Manajemen Operasi: Manajemen Keberlangsungan dan Rantai Pasokan (terjemahan). Jakarta: Salemba Empat, 2015.

[7] Z. Rival, W. S. J. Saputra, and N. K. Sari, "Aplikasi Peramalan Penjualan Menggunakan Metode Regresi Linier," Scan - J. Teknol. Inf. Dan Komun., vol. 7, no. 3, pp. 41-45, 2012.

[8] Richard and J. Rahardjo, "Improvement Manajemen Bahan Baku Kertas Dengan MRP I Pada PT. X," J. Titra, vol. 7, no. 2, pp. 129-136, 2019.

[9] C. A. Utama and Y. W. S. Watequlis S, "Pengembangan Si Stok Barang Dengan Peramalan Menggunakan Metode Double Exponential Smoothing (Studi Kasus : Pt. Tomah Jaya Elektrikal)," J. Inform. Polinema, vol. 2, no. 4, p. 147, 2016, doi: $10.33795 /$ jip.v2i4.74.

[10] M. Mansyur and E. Rohadi, "Sistem Informasi Peramalan Stok Barang Di Cv. Annora Asia Menggunakan Metode Double Exponential Smoothing," J. Inform. Polinema, vol. 2, no. 1, p. 45, 2017, doi: 10.33795/jip.v2i1.54.

[11] H. Tanuwijaya, "Penerapan Metode Winter' S Exponential Smoothing Dan Single Moving Average Dalam Sistem Informasi," in Seminar Nasional Manajemen Teknologi XI, 2010, pp. 1-10. 
[12] L. Arsyad, Peramalan Bisnis Edisi 1. Yogyakarta: Universitas Gadjah Mada, 2001.

[13] A. Sofjan, Teknik dan Metode Peramalan. Jakarta: Fakultas Ekonomi Universitas Indonesia, 1984.

[14] S. Makridakis et al., "The accuracy of extrapolation (time series) methods: Results of a forecasting competition," J. Forecast., vol. 1, no. 2, pp. 111-153, 1982, doi: 10.1002/for.3980010202.

[15] Savira, "Analisis Peramalan PEenjualan Obat Generik Berlogo (OGB) Pada PT. Indonesia Farma," in Journal of Chemical Information and Modeling, 2015, vol. 53, no. 1, pp. 1-13

[16] V. Gaspersz, Production Planning and Inventory Control. Jakarta: PT. Sun, 1998.

[17] J. Heizer and B. Render, Manajemen Operasi, Edisi 9 Terj. Chriswan Sungkono. Jakarta: Salemba Empat, 2006.

[18] M. Febrina, F. Arina, and R. Ekawati, "Peramalan jumlah permintaan produksi menggunakan metode jaringan syaraf tiruan (JST) backpropagation," J. Tek. Ind., vol. 1, no. 2, pp. 174-179, 2013. 